\title{
Analysis of Factors Affecting Consumer Purchase Decision at Online Shops
}

\author{
Muhammad Fachmi ${ }^{1)}$, Ikrar Putra Setiawan ${ }^{2)}$, Andi Hidayat ${ }^{3)}$ \\ Management Department \\ STIE Amkop Makassar \\ Makassar, Indonesia
}

\begin{abstract}
Purpose of a study, to analyze the effect of trust, promotion, and e-service quality on consumer purchasing decisions in online stores. Respondents in this study were users of online shops in Makassar City with a total sample of 100 people. Sampling was done randomly for college students who had shopped at Tokopedia, Bukalapak, and Shopee. To test the hypothesis, the researcher using Multiple Regression Analysis with a software SPSS 22.0. The findings of this study are that trust, promotion, and e-service quality have a positive and significant effect on purchasing decisions at online shops. That is, the higher the trust, the better promotions carried out, and good e-service quality, consumers will decide to shop using online shops at Tokopedia, Bukalapak, and Shopee.
\end{abstract}

Keywords:- Trust, Promotion, E-Service Quality, Purchase Decision

\section{INTRODUCTION}

The advancement of information technology influences the development of the marketing world, one of which is the increasingly widespread online market. As indicated by one of the online markets, Amazon, by providing consumers with a world-class online purchasing experience find and discover anything they might want to buy online (Kotler, Armstrong, \& Opresnik, 2018). The trend of advertising in social media has increased rapidly, and it took considerable attention (Alnemah, 2019). Even in recent years, some new approaches to marketing, ranging from imaginative websites and smartphone applications to blogs, online videos, and social media, aim to make it easier to reach consumers directly, privately and interactively (Kotler et al., 2018). This situation also occurs in China, where with the increasing popularity of the Internet and e-commerce technology, the size of online shopping users has gradually increased (Tiantian \& Liaogang, 2017). For this reason, there are many online shops in Indonesia to provide secure transactions for consumers, including Tokopedia, Bukalapak, and Shopee with innovative strategic approaches to each other.

Consumer purchasing decisions in using online shop media such as Tokopedia, Bukalapak, and Shopee, are influenced by various factors. Trust is the first factor that focuses on changing consumer purchasing decisions because if a consumer has trust in the product at the Online Shops, they will decide to purchase products at the online shops, as some research has shown that trust has a significant effect on purchasing decisions (Alnemah, 2019;
Hosseini \& Norouzi, 2017; Kore, Lamalewa, \& Mulyaningsih, 2018; Rachbini, 2018; Wibowo, Sari, \& Saidani, 2017).

Promotional factors are also a consideration in consumer purchasing decisions to shop online. In the research that has done in various places, it shows that the better the promotional activities carried out, the consumers will decide to make product purchases (Indriani, 2016; Kore et al., 2018; Tiantian \& Liaogang, 2017). This was done by several online shops, such as holding discounts, giving vouchers, and various other promotional strategies.

Consumer purchasing decisions are also influenced by e-service quality. This is because if the e-service quality perceived by consumers is getting better, then consumers will decide to purchase the product (Arslan \& Zaman, 2015; Lahindah, Merisa, \& Siahaan, 2018; Raje \& Khanna, 2012). Various strategies have been carried out by online shops such as by guaranteeing transaction security, guaranteeing the quality of products delivered, a speed of service, etc. so that it becomes a driving factor for consumers to make purchases at online shops. But other studies view that quality does not have a significant impact on consumer purchasing behaviour (Kusumah, 2015).

\section{LITERATURE REVIEW}

\section{A. Trust}

When a party has confidence that the other party involved in the exchange has reliability and integrity, it can be said that there is trust. According to the theory that, trust is defined as the positive expectations individuals have about the intent and behaviours of multiple (ShockleyZalabak, P., \& Winograd, 2000). The concept of "trust" is defined as willingness party to be vulnerable to actions of another party on the basis that the other party will take an official point of view on specific significant actions regardless of the ability to monitor or control the other party (Mayer, Davis, \& Schoorman, 1995).

\section{B. Promotion}

In the theory of marketing, promotion refers to activities that communicate product superiority and persuade target customers to buy it (Kotler et al., 2018). Li and Zhang in Indriani (2016) stated that however, promotional activates for online products or services were not successful for e-retailers because there were not effective ways to inform consumers of promotional activities. Therefore, according to Kotler in Kore et al. (2018) promotion is an attempt to communicate a product 
to consumers and then influence consumer buying interest in the company's products.

\section{E-Service Quality}

The difference between expected services and provided services is called the service quality (Arslan \& Zaman, 2015). According to Stafford \& Gillenson in Raje and Khanna (2012), service quality is more useful for service-based offerings that include information and access to information for purchasing more general online merchandise. The three main characteristics of e-services are (Raje \& Khanna, 2012):

- Can be accessed via the Internet or other electronic networks.

- Consumed by someone through the Internet or other electronic systems.

- There may be fees paid to the provider for using electronic services, or it may be free as in the case of government services.

\section{Purchase Decision}

Consumers market when they search for products, interact with companies to obtain information and make their purchases (Kotler et al., 2018). Consumer purchasing decisions are the process of decision making, and physical activities carried out by individuals by compiling, obtaining, using or disposing of goods and services (Khuong \& Duyen, 2016). One notice thing is that purchase decision does not finish with the purchase of products or services but also post purchase activities consist of consumer behaviour (Khuong \& Duyen, 2016).

Based on the above theory, the following framework can be described in this study:

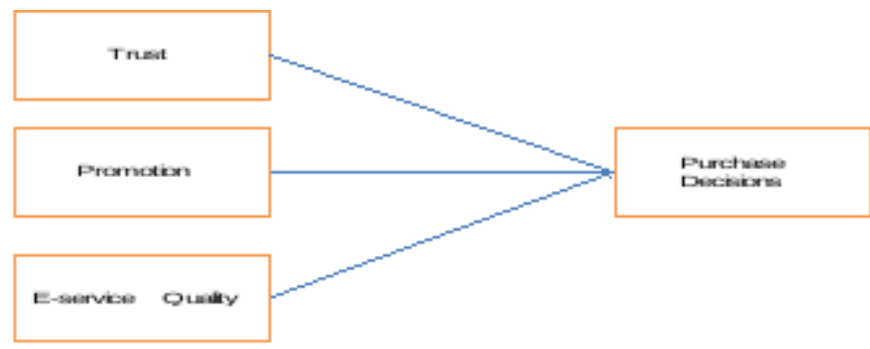

Fig 1:- Framework

\section{RESEARCH METHOD}

The method used is an empirical study with an associative research approach, which aims to determine the influence or relationship between two variables or more . The population in this study were people in the city of Makassar who were college students. The sample was determined by 100 respondents, with the distribution of questionnaires or research instruments carried out randomly using google forms, and if the sample was fulfilled and fulfilled the requirements as respondents, then the data will be analyzed further.

Questionnaires using a 5-level Likert scale, with perceptions of respondent's answer 1 were strongly disagree, 2 was disagreeing, 3 was disagreeing, 4 was agreeing, and 5 was strongly agreeing. Each indicator on the variable under study is first tested by an instrument with a valid test and a reliable test, with a validity threshold in the trial that is 0.3 and a reliable test on Cronbach's alpha $>0.6$. Furthermore, the analytical technique used is by multiple regression analysis with the t-test in testing the hypothesis.

\section{RESULTS}

\section{A. A goodness of Fit $(F)$ Test and Determination Coefficient Test}

This test is used for this test can be used to find out whether the model built meets the criteria of fit or not. The full $\mathrm{F}$ test results can be seen in the following table.

\begin{tabular}{|c|c|c|c|c|c|c|}
\hline \multicolumn{7}{|c|}{ ANOVA $^{b}$} \\
\hline & Model & $\begin{array}{l}\text { Sum of } \\
\text { Squares }\end{array}$ & df & $\begin{array}{l}\text { Mean } \\
\text { Square }\end{array}$ & $\mathrm{F}$ & Sig. \\
\hline \multirow[t]{3}{*}{1} & Regression & 563.788 & 3 & 187.929 & 64.931 & $.000^{\mathrm{a}}$ \\
\hline & Residual & 277.852 & 96 & 2.894 & & \\
\hline & Total & 841.640 & 99 & & & \\
\hline
\end{tabular}

a. Predictors: (Constant), E-Service Quality, Promotion, Trust

b. Dependent Variable: Purchase Decisions

Table 1:- F-test (Source: Processed Primary Data, 2019)

The data in table 1 , are the test results to see whether the model can meet the Fit criteria or not. Based on the findings show that the value of F-count is 64.931 with significance $<0.05$, so it can be stated that this research model meets the criteria of goodness of fit.

As for seeing the amount of contribution given from the variables of trust, promotion and e-service quality to purchase decisions, it can be seen from the determination coefficient (R2). Obtaining a determination value (R2) can be seen in the following table:

Model Summary

\begin{tabular}{|c|c|c|c|c|}
\hline Model & R & R Square & $\begin{array}{c}\text { Adjusted R } \\
\text { Square }\end{array}$ & $\begin{array}{c}\text { Std. Error of } \\
\text { the Estimate }\end{array}$ \\
\hline 1 & $.818^{\mathrm{a}}$ & .670 & .660 & 1.70126 \\
\hline
\end{tabular}

a. Predictors: (Constant), E-Service Quality, Promotion, Trust

Table 2:- Test results for the coefficient of determination (R2) (Source: Primary Data processed, 2019)

Based on the results of the coefficient of determination test above, seen from the adjusted R Square value is 0.660 or $66.0 \%$. The coefficient of determination (R2) states that trust variables, promotion and e-service quality can explain or contribute to variations in changes in consumer purchase decisions online shop by $66.0 \%$. While the remaining $34.0 \%$ is influenced by other variables not included in this study. 


\section{B. Testing the Hypothesis with the t-Test}

To obtain the partial test results can be seen in the coefficients table which is a multiple regression analysis as seen in the following table.

\begin{tabular}{|c|c|c|c|c|c|c|}
\hline \multicolumn{7}{|c|}{ Coefficients } \\
\hline & \multirow[b]{2}{*}{ Model } & \multicolumn{2}{|c|}{$\begin{array}{c}\text { Unstandardized } \\
\text { Coefficients }\end{array}$} & \multirow{2}{*}{$\begin{array}{c}\begin{array}{c}\text { Standardized } \\
\text { Coefficients }\end{array} \\
\text { Beta }\end{array}$} & \multirow[b]{2}{*}{$\mathrm{t}$} & \multirow[b]{2}{*}{ Sig. } \\
\hline & & B & $\begin{array}{l}\text { Std. } \\
\text { Error }\end{array}$ & & & \\
\hline \multirow[t]{4}{*}{1} & (Constant) & 1.756 & 1.397 & & 1.256 & .212 \\
\hline & Trust & .337 & .077 & .352 & 4.352 & .000 \\
\hline & Promotion & .328 & .074 & .334 & 4.457 & .000 \\
\hline & $\begin{array}{c}\text { E-Service } \\
\text { Quality }\end{array}$ & .313 & .080 & .288 & 3.900 & .000 \\
\hline
\end{tabular}

a. Dependent Variable: Purchase Decisions

Table 3:- Partial Testing (t-Test) (Source: Primary Data Processed, 2019)

Based on table 3, it can be seen that the results of multiple linear regression equations from this research model are as follows:

$$
Y=1,756+0,337 X_{1}+0,328 X_{2}+0,313 X_{3}
$$

The results of testing the hypothesis in this study are as follows:

a) Testing the influence of trusts on the consumer purchase decisions online shop

The hypothesis proposed in this study are:

- Ha: trust has a positive and significant effect on the consumer purchase decisions online shop

Partial testing is analyzed through the magnitude of the calculated t-value obtained then compares with the ttable value. When the value is calculated $>t$-table, then the null hypothesis (H0) is rejected, and the alternative hypothesis (Ha) is accepted. Conversely, if the value of tcount $<\mathrm{t}$-table then the null hypothesis (H0) is accepted, and the alternative hypothesis $(\mathrm{Ha})$ is rejected. Based on the results of the analysis in table 3 , the calculated value of the trust variable $(\mathrm{X} 1)$ is 4,352 with a significant level of 0,000 . And obtained a t-table value of 1,985 . Thus, the $t-$ count value is greater than the t-table value $(4,352>1,985)$ and is positive, and the significance is smaller than 0,050 , so it can be stated that trust (X1) has a positive and significant effect on the consumer purchase decisions online shop ( $\mathrm{Y})$. Then it can be concluded that the hypothesis in this study is proven.

b) Testing the influence of trusts on the consumer purchase decisions online shop

The hypothesis proposed in this study are:
- Ha: Promotion has a positive and significant effect on the consumer purchase decisions online shop

Partial testing is analyzed through the magnitude of the calculated t-value obtained then compares with the $t$ table value. When the value is calculated $>\mathrm{t}$-table, then the null hypothesis (H0) is rejected, and the alternative hypothesis (Ha) is accepted. Conversely, if the value of tcount $<$ t-table then the null hypothesis (H0) is accepted, and the alternative hypothesis (Ha) is rejected. Based on the results of the analysis in table 3 , the calculated value of the promotion variable (X2) is 4,457 with a significant level of 0,000 . And obtained a t-table value of 1,985 . Thus, the $t-$ count value is greater than the t-table value $(4,457>1,985)$ and is positive, and the significance is smaller than 0,050 , so it can be stated that promotion (X2) has a positive and significant effect on the consumer purchase decisions online shop ( $\mathrm{Y}$ ). Then it can be concluded that the hypothesis in this study is proven.

c) Testing the influence of e-service quality on the consumer purchase decisions online shop

The hypothesis proposed in this study are:

- Ha: E-Service quality has a positive and significant effect on the consumer purchase decisions online shop

Partial testing is analyzed through the magnitude of the calculated t-value obtained then compares with the ttable value. When the value is calculated $>\mathrm{t}$-table, then the null hypothesis (H0) is rejected, and the alternative hypothesis $(\mathrm{Ha})$ is accepted. Conversely, if the value of $\mathrm{t}$ count $<$ t-table then the null hypothesis (H0) is accepted, and the alternative hypothesis (Ha) is rejected. Based on the results of the analysis in table 3 , the calculated value of the e-service quality variable (X3) is 3,900 with a significant level of 0,000 . And obtained a t-table value of 1,985. Thus, the $\mathrm{t}$-count value is greater than the t-table value $(3,900>$ $1,985)$ and is positive, and the significance is smaller than 0,050 , so it can be stated that e-service quality (X3) has a positive and significant effect on the consumer purchase decisions online shop ( Y). Then it can be concluded that the hypothesis in this study is proven.

\section{CONCLUSIONS}

Research conducted on online shop users, namely Tokopedia, Bukalapak, and Shopee, especially among college students, has proven that the higher the level of trust, promotion, and e-service quality, the more purchase decisions for online shopping. Trust is the most dominant factor in influencing consumer purchase decisions at online shops.

This study implies that, the need to identify and analyze other factors that can encourage increased purchase decisions from consumers, because the adjusted $r$ square value is only $66 \%$, while the rest is influenced by other variables that have not been studied, including factors of price, product quality, and others so. 


\section{REFERENCES}

[1]. Alnemah, F. A. (2019). Impact of Social Media on Purchase Intention of Airline Passengers: A Study in the Kingdom of Bahrain. International Journal of Innovative Science and Research Technology, 4(1).

[2]. Arslan, M., \& Zaman, R. (2015). Impact of Brand Image and Service Quality on Consumer Purchase Intentions. A Study of Retail Stores in Pakistan: GRIN Verlag.

[3]. Hosseini, M., \& Norouzi, H. (2017). Investigating the impact of consumer trust on loyalty and purchase intention of food store brands: Case study: Palladium shopping mall in Tehran. International Review of Management and Marketing, 7(4), 138-146.

[4]. Indriani, I. A. D. (2016). Analysis The Factors Influence Consumer Buying Decision On Online Shopping Clothing For Consumer In Manado. Jurnal EMBA: Jurnal Riset Ekonomi, Manajemen, Bisnis dan Akuntansi, 4(1).

[5]. Khuong, M. N., \& Duyen, H. T. M. (2016). Personal Factors Affecting Consumer Purchase Decision towards Men Skin Care Products - A Study in Ho Chi Minh City, Vietnam. International Journal of Trade, Economics and Finance, 7(2), 44-50. doi:10.18178/ijtef.2016.7.2.497

[6]. Kore, E. L. R., Lamalewa, F., \& Mulyaningsih, A. (2018). The Influence of Promotion, Trust, and Convenience to Online Purchase Decisions. International Journal of Mechanical Engineering and Technology (IJMET), 9(10).

[7]. Kotler, P., Armstrong, G., \& Opresnik, M. O. (2018). Principles of Marketing (17e Global Edition ed.). United Kingdom: Pearson Education Limited.

[8]. Kusumah, R. (2015). Analyze the Effect of Trust, Price, Quality and Perceived risk Toward Consumer Purchase Behavior in Online Shops Instagram. Jurnal Berkala Ilmiah Efisiensi, 15(5).

[9]. Lahindah, L., Merisa, M., \& Siahaan, R. A. (2018). The Influence of Product Innovation and Service Quality to Buying Decision and the Impact to Repeat Buying at Progo Road Bandung. The Asian Journal of Technology Management (AJTM), 11(2), 118-124. doi:10.12695/ajtm.2018.11.2.4

[10]. Mayer, R., Davis, J., \& Schoorman, F. (1995). An Integrative Model of Organizational Trust. The Academy of Management Review, 20(3).

[11]. Rachbini, W. (2018). The Impact of Consumer Trust, Perceived Risk, Perceived Benefit on Purchase Intention and Purchase Decision. International Journal of Advanced Research, 6(1), 1036-1044. doi:10.21474/ijar01/6317

[12]. Raje, A., \& Khanna, V. (2012). Impact of E-Service Quality on Consumer Purchase Behaviour in an OnLine Shopping. IJCSMS International Journal of Computer Science and Management Studies, 12(02), $1-5$.

[13]. Shockley-Zalabak, P., E., K, \& Winograd, G. (2000). Organizational trust: What it means, why it matters. Organization Development Journal, 18(4).
[14]. Sugiyono, P. Dr. 2010. Metode Penelitian Kuantitatif, Kualitatif, dan R\&D. Bandung: CV Alfabeta.

[15]. Tiantian, T., \& Liaogang, H. (2017). Research on the Influence of Price Promotion on Consumer Purchase Decision under Network Environment. Paper presented at the 2nd International Conference on Education Technology and Economic Management (ICETEM 2017).

[16]. Wibowo, S. F., Sari, E. P., \& Saidani, B. (2017). The Effect Of Trust And Brand Image On Purchase Decision (Toyota Car Survey In Jakarta Region). JRMSI-Jurnal Riset Manajemen Sains Indonesia, 8(2), 318-338. 